University of Nebraska - Lincoln

DigitalCommons@University of Nebraska - Lincoln

Faculty Publications from the Harold W. Manter Laboratory of Parasitology

4-1997

\title{
A New Coccidian from Acomys cahirinus Desmarest, 1819, from Evolution Canyon, Lower Nahal Oren, Mount Carmel, Israel
}

\author{
Lee Couch \\ University of New Mexico, Icouch@unm.edu \\ Leon Blaustein \\ University of Haifa \\ Donald W. Duszynski \\ University of New Mexico, eimeria@unm.edu \\ Georgy Shenbrot \\ Ben Gurion University \\ Eviatar Nevo \\ University of Haifa
}

Follow this and additional works at: https://digitalcommons.unl.edu/parasitologyfacpubs

Part of the Parasitology Commons

Couch, Lee; Blaustein, Leon; Duszynski, Donald W.; Shenbrot, Georgy; and Nevo, Eviatar, "A New Coccidian from Acomys cahirinus Desmarest, 1819, from Evolution Canyon, Lower Nahal Oren, Mount Carmel, Israel" (1997). Faculty Publications from the Harold W. Manter Laboratory of Parasitology. 175. https://digitalcommons.unl.edu/parasitologyfacpubs/175

This Article is brought to you for free and open access by the Parasitology, Harold W. Manter Laboratory of at DigitalCommons@University of Nebraska - Lincoln. It has been accepted for inclusion in Faculty Publications from the Harold W. Manter Laboratory of Parasitology by an authorized administrator of DigitalCommons@University of Nebraska - Lincoln. 


\title{
A NEW COCCIDIAN FROM ACOMYS CAHIRINUS DESMAREST, 1819, FROM EVOLUTION CANYON, LOWER NAHAL OREN, MOUNT CARMEL, ISRAEL
}

\author{
Lee Couch, Leon Blaustein*, Donald W. Duszynski, Georgy Shenbrot†, and Eviatar Nevo* \\ Department of Biology, The University of New Mexico, Albuquerque, New Mexico 87131
}

\begin{abstract}
In 1994, fresh fecal samples were collected and examined for coccidian parasites from 43 spiny mice (Acomys cahirinus) and from 60 wood mice (Apodemus mystacinus). The 2 genera of rodents inhabit an area in Lower Nahal Oren, Mount Carmel, Israel, known as Evolution Canyon, which consists of opposite-facing slopes that are geologically identical, but microclimatically very different. Acomys cahirinus is found primarily on the warmer and drier south-facing slope (SFS), whereas $A$. mystacinus primarily inhabits the cooler and wetter north-facing slope (NFS). None of the samples from the A. mystacinus contained coccidia, but 6 of $43(14 \%)$ A. cahirinus individuals were discharging eimerian oocysts that we describe herein as a new species. Five of the 6 positive samples were from the SFS. Sporulated oocysts are ovoidal to subspheroidal, $26.5 \times 22.9$ $(21-29 \times 19-26) \mu \mathrm{m}$, without a micropyle, but with an oocyst residuum of 1 to several large clear globules and a medium-sized refractile polar body; they contain lemon-shaped sporocysts, $10.4 \times 8.1(10-11 \times 7-10) \mu \mathrm{m}$, with a sporocyst residuum and Stieda body, but no sub-/or parastieda body. Sporozoites lie side by side, completely filling oocysts; each contains a large posterior refractile body.
\end{abstract}

A unique canyon in Lower Nahal Oren, Mount Carmel, Israel, recently referred to as Evolution Canyon (Nevo, 1995), provides a convenient site to study the evolution of rodents that are ecologically segregated in relation to microclimatic factors. The north-facing slope (NFS) and the south-facing slope (SFS) share the same geology, but are separated by a valley floor approximately $100 \mathrm{~m}$ wide. Despite such close proximity, these opposing slopes have remarkably different biological communities (Nevo, 1995), due to considerably different inputs of solar radiation (up to $300 \%$ greater on the SFS than on the NFS) (H. Kutiel and L. Sher, unpubl. obs.). The SFS is basically a savannahlike, open park forest, consisting largely of perennial and annual grasses, patches of shrubs (mainly Pistacia lentiscus), an occasional carob tree (Ceratonia siliqua), and considerable open rock surfaces. By contrast, the NFS is a dense maquis of live oak (Quercus calliprinos) and shrubs. Overall, the macroclimate of both slopes is Mediterranean, with an average rainfall of about $600 \mathrm{~mm}$ that falls almost exclusively from November through April. The rest of the year is relatively dry. The dramatic interslope microclimate divergence is caused by the substantially higher solar radiation on the SFS, resulting in a xeric, stressful savannah.

The rodent community on the SFS is dominated by the spiny mouse, Acomys cahirinus Desmarest, 1819, with a much smaller proportion of the wood mouse Apodemus mystacinus Danford and Alston, 1877 (see Results). The NFS is dominated numerically by $A$. mystacinus, with a smaller population of $A$. cahirinus (Blaustein et al., 1996; L. Blaustein, G. Shenbrot, and E. Nevo, unpubl. obs.).

Acomys spp. typically inhabit arid regions that consist of rocky areas or dry woodlands/savannahs, such as that of the SFS. They shelter in rocky crevices, cracked soil, or sometimes other rodent burrows. Their diet consists primarily of plant material such as grains and grasses, although they are occasionally omnivorous (Nowak and Paradiso, 1983).

In contrast, Apodemus spp. primarily inhabit the woodlands

Received 10 June 1996; revised 3 October 1996; accepted 3 October 1996.

* Institute of Evolution, University of Haifa, Mount Carmel, Haifa 31905, Israel.

† Ramon Science Center, Ben Gurion University, Mitze Ramon, Israel. and forests of the NFS (Blaustein et al., 1996). They live in burrows, usually with many chambers, under tree roots. Their diet consists of roots, grains, seeds, berries, and insects. Additionally, they tend not to travel beyond a radius of $180 \mathrm{~m}$ from their burrows (Crawley, 1969).

To date, no studies have been done on the parasites that may infect rodents from this locality. Also, because the opposite slopes represent dramatically different biotic environments due to differences in solar radiation and other climatic factors such as rainfall and temperature, we were interested in determining if these factors affect parasite (coccidian) prevalence in the rodents inhabiting Evolution Canyon.

\section{MATERIALS AND METHODS}

From July through December 1994 (primarily the dry season), 43 spiny mice and 60 wood mice were live-trapped from Evolution Canyon. Fresh fecal samples were collected from each animal upon capture and placed in separate vials containing $2 \%(\mathrm{w} / \mathrm{v})$ aqueous potassium dichromate $\left(\mathrm{K}_{2} \mathrm{Cr}_{2} \mathrm{O}_{7}\right)$, mixed thoroughly, and stored for approximately 2-4 wk at ambient temperature (ca. 2l C). Animals were released after collection of feces. Samples were returned to Albuquerque, New Mexico, and processed as detailed by Duszynski et al. (1982), and stored at 4 C. Oocysts were measured and photographed within 30 days after arrival. All measurements are given in $\mu \mathrm{m}$ with size ranges in parentheses following the means.

\section{RESULTS}

Acomys cahirinus dominated the SFS whereas A. mystacinus dominated the NFS. During the period of study, 152 Acomys and 52 Apodemus were collected on the SFS. In contrast, 34 Acomys and 93 Apodemus were collected on the NFS. Density of Acomys on the SFS (152 of 204, 75\%) was significantly higher than that of Apodemus (52 of 204, 25\%; Fisher's Exact Test, $P<0.0001$ ), whereas the reverse was true for the NFS, with a higher density of Apodemus (93 of 127, 73\%) vs. Acomys (34 of 127, 27\%) (L. Blaustein, unpubl. observ.). Fecal samples were obtained from $43 \mathrm{~A}$. cahirinus and from 60 A. mystacinus. None of the samples from Apodemus contained coccidian oocysts, but 6 of the $43(14 \%)$ A. cahirinus samples were positive for oocysts, representing a species of eimerian that we describe here as new. Five of the 6 positive samples were from the SFS. 

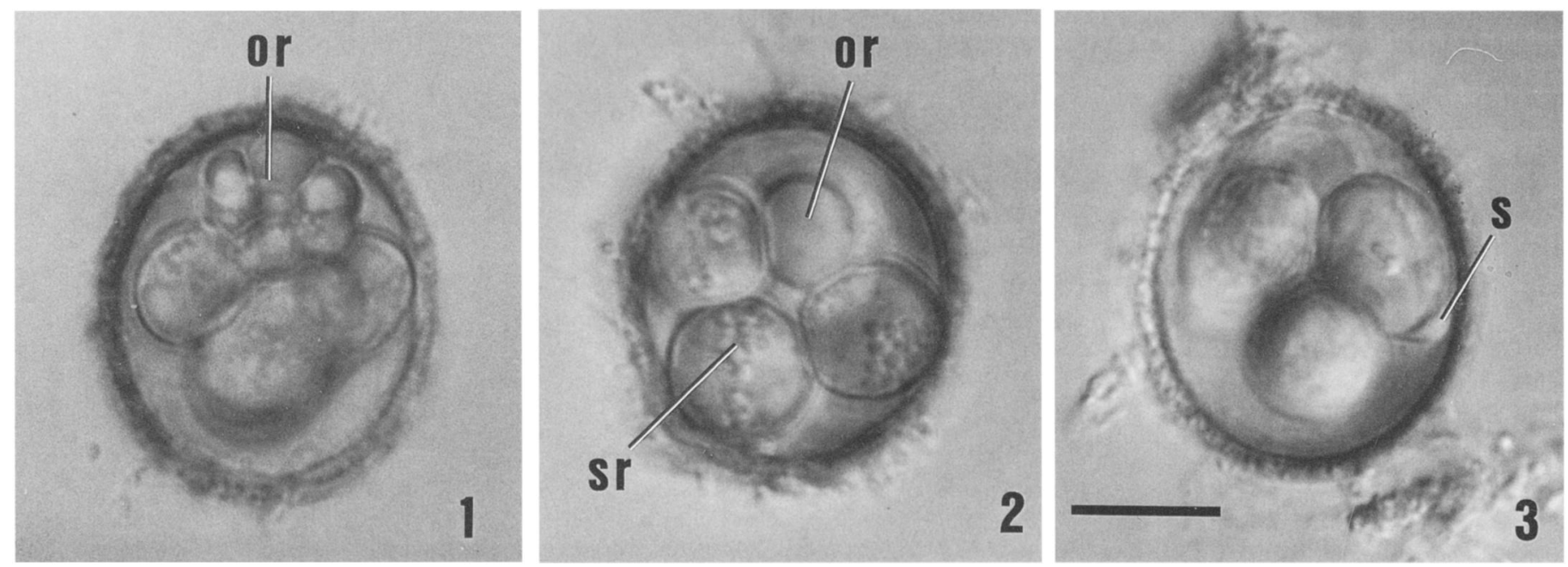

FIGUREs 1-3. Photomicrographs of sporulated oocysts obtained from the feces of Acomys cahirinus in Lower Nahal Oren, Mount Carmel, Israel. Scale bar $=10 \mu \mathrm{m}$ for all figures. Abbreviations: or, oocyst residuum; s, Stieda body; sr, sporocyst residuum.

\section{DESCRIPTION}

\section{Eimeria cahirinensis n. sp.}

(Figs. 1-4)

Oocyst ovoidal to subspheroidal (Figs. 1-3), wall $\sim 1.5$, composed of 2 layers: outer layer slightly striated and pitted, $\sim 3 / 4$ of total thickness; inner layer smooth, transparent; oocyst residuum consists of either 1 large clear globule or several large granules (Figs. 1, 2); micropyle absent, but medium sized, refractile polar body present; sporulated oocysts $(n=20) 26.5 \times 22.9(21-29 \times 19-26)$ with length : width ratio (=shape index, SI) $1.2(1.0-1.3)$; sporocysts $(\mathrm{n}=20)$ lemon-shaped, $10.4 \times 8.1(10-11 \times 7-10)$ with SI $1.3(1.1-1.4)$; somewhat wide, thick

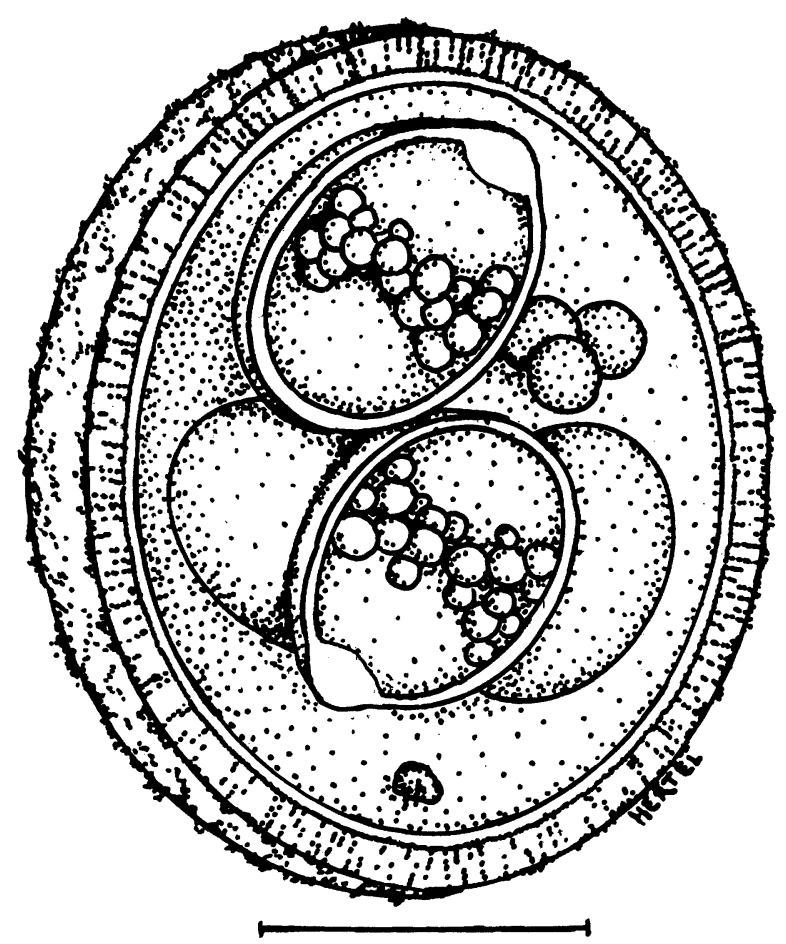

FIGURE 4. Composite line drawing of sporulated oocyst of the eimerian collected from the feces of Acomys cahirinus from Lower Nahal Oren, Mount Carmel, Israel. Scale bar $=10 \mu \mathrm{m}$.
Stieda body present (Fig. 3), sub-/and parastieda body absent; sporocyst residuum of medium-sized granules that appear in clusters across center of sporocyst between sporozoites (Fig. 2); 2 sporozoites present, each with posterior refractile body, lying head to tail, and filling entire sporocyst.

\section{Taxonomic summary}

Type host: Acomys cahirinus Desmarest, 1819 (Muridae: Murinae), spiny mouse.

Type locality: Israel, Mount Carmel, Nahal Oren, south-facing slope, Evolution Canyon, $32^{\circ} 43^{\prime} \mathrm{N}, 34^{\circ} 58^{\prime} \mathrm{E}$.

Prevalence: Found in 6 of $43(14 \%)$ A. cahirinus; 2 samples from the SFS and 1 sample from the NFS had unsporulated oocysts, but these were identical in size and general oocyst structure to the sporulated oocysts.

Site of infection: Unknown, oocysts collected from feces.

Material deposited: Phototype (see Bandoni and Duszynski, 1988) of sporulated oocysts in the U.S. National Parasite Collection, Beltsville, Maryland, USNPC no. 86844.

Etymology: The nomen triviale is derived from the species name of the host and -ensis (L., belonging to).

\section{Remarks}

Within the subfamily Murinae, to which Acomys belongs, there are 119 genera (Wilson and Reeder, 1993). Only 14 of the 119 (12\%) genera have coccidian species described from them (82 Eimeria spp. and 10 Isospora spp.), but none has been described from Acomys until now. Only 2 of these previously described Eimeria spp. from genera of this subfamily are similar to the 1 that we describe here as new (see Levine and Ivens, 1990). Oocysts of this new species most closely resemble those of Eimeria nesokia Mirza, 1975, described from the short-tailed bandicoot rat, Nesokia indica Gray and Hardwicke, 1830, in Egypt and Iraq, in size and shape of their oocysts, in wall structure, and in shape of their sporocysts. Oocysts of the proposed species differ, however, by being slightly larger $(26.5 \times 22.9$ vs. $24 \times 20)$, and by having sporocysts with a Stieda body, which those of $E$. nesokia lack. Oocysts of the new species also resemble those of Eimeria pretoriensis De Vos and Dobson, 1970, described from the 4-striped grass mouse, Rhabdomys pumilio Sparrman, 1784, from South Africa, in size and shape of their oocysts, in wall structure, and in size (but not shape) of their sporocysts. Oocysts of the proposed species differ by being slightly larger $(26.5 \times 22.9$ vs. $24 \times 19)$, and by having sporocysts that are lemon-shaped with a wide, thick Stieda body vs. an elliptical shape with a small Stieda body. In addition, the sporocysts of $E$. pretoriensis have a sporocyst residuum composed of large granules that almost completely obscure the sporozoites, whereas those of this species are medium-sized granules clustered along the center of the sporocyst. 
Finally, these oocysts also closely resemble those of Eimeria arizonensis Levine, Ivens and Kruidenier, 1957, described from the piñon mouse, Peromyscus truei Shufeldt, 1885 (subfamily Sigmodontinae), from Arizona, which are similar in shape of oocyst and sporocysts. The oocysts from A. cahirinus differ by being slightly larger overall (26.5 $\times 22.9$ vs. $23.6 \times 20.8)$, by having less elongate sporocysts $(10.4 \times$ 8.1 vs. $12.1 \times 7.7)$, and by having a slightly wider and flatter Stieda body. In addition, E. arizonensis has only been described from North American hosts.

\section{DISCUSSION}

The period of time that coccidian oocysts survive in the natural environment of their hosts is dependent on such factors as temperature, vegetation, shade, and moisture. Some coccidian oocysts can remain viable in their external environment for 5286 wk (Farr and Wehr, 1949; Koutz, 1950; Frenkel et al., 1975), but the length of survival is apparently species dependent and, thus, unknown for most coccidia. Oocysts would probably survive longer in mesic environments with little direct solar (ultraviolet) radiation and with substantive vegetation to provide shade and retain moisture. The SFS is an area that is climatically unpredictable and, seemingly, less conducive to oocyst survival because it is warmer and more xeric, has more solar radiation, and has less vegetation than does the NFS. In addition, our collections were made during the dry season. Surprisingly, 5 of the 6 infected Acomys in this study were taken from the SFS.

In another rodent species from Israel, Spalax ehrenbergi, prevalence also was higher in rodents that inhabited the more xeric regions (Couch et al., 1993). In S. ehrenbergi, host genetic diversity (chromosomal and genic) increases as habitats become more climatically unpredictable (Nevo and Cleve, 1978; Nevo, $1985,1995)$, which is positively correlated with parasite prevalence and parasite success in these hosts (Couch et al., 1993). A similar observation was made by Gardner and Duszynski (1990) on the rodent tuco-tuco (genus Ctenomys) in Bolivia, a species that exhibits the highest known chromosomal variation of all mammals. Acomys spp. also are known to show considerable genetic variation with $2 n$ ranging from 36 to 38 to 66 in different species (Nevo, 1985). The $A$. cahirinus examined in this study had a $2 \mathrm{n}=38$. Perhaps this species also exhibits more genetic diversity, is more recently derived in response to the harsher environment, or both. The SFS habitats are more physiologically stressful for species living there than those that inhabit the NFS. Thus, if increased genetic diversity is a result of environmental stress on the host, then this reponse to stress may further contribute to the higher incidence of infection in Acomys spp. when coccidia are present in its xeric natural environment.

Although the habitat and habits of Apodemus spp. are more conducive to oocyst survival, (i.e., temperate and moist, use of burrow systems), the $A$. mystacinus we examined were uninfected with coccidia. In contrast, other Apodemus spp. studied in Japan, Russia, and the British Isles all have had substantial infections with several species of coccidia (Musaev and Veisov, 1963; Glebezdin, 1973; Lewis and Ball, 1983; Wash et al., 1985). Apodemus spp. do not exhibit high genetic diversity (Filippucci et al., 1989; Nevo et al., 1997), and if genetic diversity is indeed a response to harsher environments, then one would not expect to see such diversity in an environment such as that of the more mesic and less climatically unpredictable NFS.
Wasser et al. (1995) described a large number of species of antibiotic fungi found in Evolution Canyon; we speculate that this may contribute in part to the low prevalence, particularly in the Apodemus. For example, 15 species of Penicillium (of 100 known species worldwide) were isolated among soil micromycetes in the canyon. Perhaps the abundance of fungal spores lends itself to providing some medicinal value that may inhibit coccidial infections in these rodent species. In particular, A. mystacinus may be better protected due to an increased growth of the fungi on the more mesic NFS (12 species vs. 6 species on the SFS).

\section{ACKNOWLEDGMENTS}

This work was supported in part by a grant (1426) funded by the Israeli Ministry of Science and GSF (Forchungszentrum fuer Umwelt und Gesundheit Gmbh, Neurherberg) awarded to L.B., E.N., and Broder Breckling. E.N. also would like to acknowledge the Ancell-Tiecher Research Foundation and Israeli Discount Bank Chair of Evolutionary Biology. L.C. would like to acknowledge the Albuquerque T-VI for supporting this work by providing time for, and encouragement of, professional activities to study these organisms. Finally, we would like to thank Lynn Hertel for the line drawing of the oocyst.

\section{LITERATURE CITED}

BAndoni, S. M., AND D. W. DuszYnski. 1988. A plea for improved presentation of type material for coccidia. Journal of Parasitology 74: 519-523.

Blaustein, L., B. P. Kotler, and E. Nevo. 1996. Rodent species diversity and microhabitat use along opposing slopes of a Mediterranean microsite: Lower Nahal Oren, Mount Carmel, Israel. Israel Journal of Zoology (in press).

Couch, L., D. W. Duszynski, And E. Nevo. 1993. Coccidia (Apicomplexa), genetic diversity, and environmental unpredictability of four chromosomal species of the subterranean superspecies Spalax ehrenbergi (mole-rat) in Israel. Journal of Parasitology 79: 181-189.

Crawley, M. C. 1969. Movements and home-ranges of Cleithrionomys glareolus Schreber and Apodemus sylvaticus L. in north-east England. Oikos 20: 310-319.

DUSZYNSKI, D. W., G. EASThAM, AND T. L. YATES. 1982. Eimeria from jumping mice (Zapus spp.): A new species and genetic and geographic features of $Z$. hudsonius luteus. Journal of Parasitology 68: 1146-1148.

FARR, M. M., AND E. E. WEHR. 1949. Survival of Eimeria acervulina, $E$. tenella, and E. maxima oocysts in soil under various field conditions. Annals of the New York Academy of Sciences 52: 468472 .

Frenkel, J. K., A. Ruiz, and M. Chinchilla. 1975. Soil survival of Toxoplasma oocysts in Kansas and Costa Rica. The American Journal of Tropical Medicine and Hygiene 24: 439-443.

FilippucCi, M. G., S. Simson, AND E. Nevo. 1989. Evolutionary biology of the genus Apodemus Kaup, 1829 in Israel. Allozymic and biometric analysis with description of a new species: Apodemus hermonensis (Rodentia, Muridae). Bolletino Zoologico 56: 361-376.

Gardner, S. L., AND D. W. DuszYnSKI. 1990. Polymorphism of eimerian oocysts can be a problem in naturally infected hosts: An example from subterranean rodents in Bolivia. Journal of Parasitology 76: $805-811$.

Glebezdin, V. S. 1973. Coccidial infestation of Apodemus sylvaticus L. in the Kara-Kala region of the Turkmen SSR. Izvestia Akademii Nauk Turkmenskoi SSR, seriya Biologogicheskikh Nauk 4: 57-62.

Koutz, F. R. 1950. The survival of avian coccidia in the soil. The Speculum 3: 1-5.

LEVINE, N. D., AND V. IvENS. 1990. The coccidian parasites of rodents. CRC Press, Inc. Boca Raton, Florida, 228 p.

LEwIS, D. C., AND S. J. BALL. 1983. Species of Eimeria of small wild 
rodents from the British Isles, with descriptions of two new species. Systematic Parasitology 5: 259-270.

Musaev, M. A., AND A. M. Veisov. 1963. Coccidia of the wood mouse Apodemus sylvaticus L. in Azerbaidzhan. Izvestia Akademii Nauk Azerbaidzhanskoi SSR 5: 3-14.

Nevo, E. 1985. Genetic differentiation and speciation in spiny mice, Acomys. Acta Zoologica Fennica 170: 131-136.

. 1995. Asian, African and European biota meet across phylogeny at "Evolution Canyon", Israel. Proceedings of the Royal Society of London 262: 149-155.

, AND H. CleVE. 1978. Genetic differentiation during speciation. Nature 275: 125-126.

-, M. G. Filippucci, T. Pavlicek, O. Gorlova, G. Shenbrot, E. IVANITSKAYA, AND A. BEILES. 1997. Genotypic and phenotypic divergence of rodents (Acomys cahirinus and Apodemus mystacinus) at "Evolution Canyon": Micro- and macroscale parallelism. Acta Theriologica (in press).
NowaK, R. M., AND J. L. Paradiso. 1983. Walker's mammals of the world, 4th ed. The Johns Hopkins University Press, Baltimore, Maryland, 1,362 p.

Wash, C. D., D. W. Duszynski, and T. L. Yates. 1985. Eimerians from different karyotypes of the Japanese wood mouse (Apodemus spp.), with descriptions of two new species and a redescription of Eimeria montgomeryae Lewis and Ball, 1983. Journal of Parasitology 71: 808-814.

Wasser, S. P., E. Nevo, O. N. Vonograda, I. L. Navrotskaya, I. A. Ellanskaya, P. A. Volz, V. M. Virchenko, P. M. TSARENKo, and S. Y. A. KondRATYUK. 1995. Diversity of crytpogamic plants and fungi in "Evolution Canyon," Nahal Oren, Mount Carmel Natural Preserve, Israel. Israel Journal of Plant Science 43: (in press).

WiLSON, D. E., AND D. M. ReEDER (eds.). 1993. Mammal species of the world. Smithsonian Institution Press, Washington, D.C., 1,207 p. 